\title{
IRISH FILM AND MEDIA STUDIES PUBLICATIONS
}

\author{
The Year in Review- 2015 \\ Ruth Barton (ed.)
}

Copyright (c) 2016 by the authors. This text may be archived and redistributed both in electronic form and in hard copy, provided that the authors and journal are properly cited and no fee is charged for access.

\section{Introduction}

Ruth Barton

Rethinking Occupied Ireland: Gender and Incarceration in Contemporary Irish Film by Jessica Scarlata

Ciara Chambers

Making Time in Stanley Kubrick's Barry Lyndon. Art, History, and Empire

by Maria Pramaggiore

Elisa Pezzotta

Ireland and Cinema: Culture and Contexts

by Barry Monahan (ed.)

Lance Pettitt

Visions of Ireland Gael Linn's Amharc Éireann film Series, 1956-1964

by B. Mairéad Pratschke

Seaghan Mac an tSionnaigh 


\section{Irish Film and Media Studies Publication. Introduction}

Ruth Barton

Another year, another four substantial contributions to scholarship on Irish cinema. As Lance Pettit notes in his review of Ireland and Cinema: Culture and Contexts, it has also been a time of official retirements, notably those of Martin McLoone and Kevin Rockett. And, to plug a local event, both those luminaries of Irish film studies, as well as many other names from the discipline, will be attending and contributing to Trinity College's 'Irish Cinema: The National and the International' symposium for Kevin Rockett to be held on 20 May of this year.

What is so welcome about these volumes is that many of their authors and contributors come from outside Ireland. Irish film studies is far from a parochial affair. It is eclectic in its range, its address, and its theoretical approaches. It is taught in university departments around the world, while its companion, the Irish film festival, pops up all across the globe.

This has always been intended as a review section for publications on all genres of Irish media but it is still Film Studies that dominate, an irony given the rush to write off Film Studies as obsolete. Still, I hope that this time next year, or in the near future, we will be including more publications on Irish media, television, gaming and digital culture. Meanwhile, congratulations to the authors and editors of these volumes.

Ruth Barton is lecturer in Film Studies at Trinity College Dublin and the author of a number of books on Irish cinema, including Jim Sheridan: Framing the Nation (2002); Irish National Cinema (2004) and Acting Irish in Hollywood (2006). She is also editor of Screening Irish-America (2009). Her most recent monograph is Rex Ingram: Visionary Director of the Silent Screen (University Press of Kentucky, 2014). She is currently co-editing, with Simon Trezise, a reader on music and silent cinema.
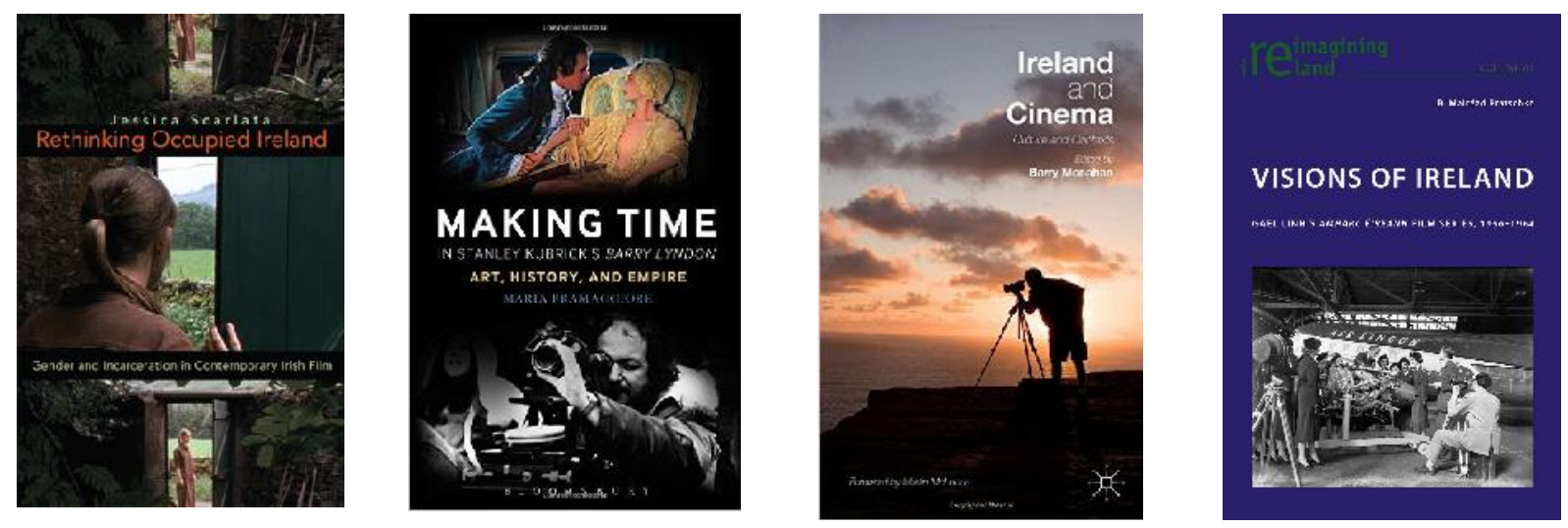

ISSN 1699-311X 
Rethinking Occupied Ireland: Gender and Incarceration in Contemporary Irish Film

Jessica Scarlata

Syracuse, NY: Syracuse University Press. 2014

ISBN: 978-0-8156-3332-7

Reviewer: Ciara Chambers

This study focuses on the concepts of gender and incarceration in Irish film in order to interrogate how filmmakers have chosen to critique Irish nationalism and "confront the brutalities of Irish history" (253). It examines ten films ranging from the commercially successful to the aesthetically engaging but less accessible. These films share a common sense of entrapment (some more overtly than others): Maeve (Pat Murphy 1981), Anne Devlin (Pat Murphy 1984), Four Days in July (Mike Leigh 1984), Hush-aBye Baby (Margo Harkin 1989), Some Mother's Son (Terry George 1996), H3 (Les Blair 2001), Silent Grace (Maeve Murphy 2001), Sinners (Aisling Walsh 2002), The Magdalene Sisters (Peter Mullan 2002), Hunger (Steve McQueen 2008). The book also refers to other filmic examples, photography, murals, political pamphlets and art. Consideration of the visual recordings of the Prisons Memory Archive, a collection of interviews on site with former prisoners and staff at Armagh Gaol and The Maze/Long Kesh, which may have enriched the book's contextual discourse, is however, absent.

The study is competently written, providing thorough and often visceral textual analyses of the chosen films. It engages with writings on Irish cinema by stalwarts like Martin McLoone, John Hill and Luke Gibbons and embraces cultural studies through reference to sociopolitical theorists Walter Benjamin, Michel Foucault and Stuart Hall, amongst others. In its theoretical framework it leans more towards the historical than the cinematic context and prioritizes the local and socio-political over broader gender/feminist discourse. Nevertheless, it proficiently navigates through the complex web of twentieth century Irish politics, drawing upon international parallels where useful, making this an accessible text for those with little knowledge of Irish history. The study interrogates visual tropes such as the Blanketman and Mother Ireland from a range of perspectives and captures the problematic nature of such cultural expressions of masculinity and femininity.

Turning her attention to Mike Leigh's Four Days in July in the introduction, Scarlata recognizes in the film romantic notions of Irish nationalism that gender the nation as female, associating its femininity with suffering, subjugation and confinement. Scarlata sets up this position to scrutinize notions of suffering and martyrdom associated with the colonized Irish male that become problematic within this framework. Equally significant is the book's interrogation of nationalism's colonization of women through the forces of church and patriarchy. In the following chapter exploring Maeve and Hush-a-Bye Baby, Scarlata explains how these films reveal "the gendered politics of occupation and the ways that space is claimed, guarded and placed under surveillance by a range of competing forces that often converge on the bodies of women" (2014: 35). Occupation, surveillance, and attempts at policing the body are undertaken here by both the British military (in Maeve) and the Catholic Church (in Hush-aBye Baby).

Scarlata turns to notions of masculinity next, specifically through exploration of the 1981 Hunger Strikes and "dirt" protests (she eloquently

ISSN 1699-311X 
outlines the significant differences between "dirt" and "dirty").This chapter explores Terry George's commercially conventional Some Mother's Son, Les Blair's H3, characterized elsewhere as adeptly visualizing prisoners' selfabjection (Blaney in Rockett and Hill (Eds.) 2006: 87), and artist Steve McQueen's aesthetically provocative filmic debut Hunger. Scarlata notes that both Hill and McLoone, while recognizing George's film as problematic, commend its tribute to the families of hunger strikers, while she highlights its "insistence on a depoliticized image of motherhood" (2014: 158). In fact, there is a suggestion that while George chooses zones of heightened political tension as the settings for his films (Northern Ireland, Rwanda) he is not interested in complex political analysis and therefore spectacle and sentiment win out at the expense of astute cultural commentary or political nuance, as is often the case with historical cinema. Hunger and $H 3$, Scarlata asserts, shift focus from the larger narrative and visual scale to the minute. Focus on small details becomes exquisitely artistic in Hunger, drawing attention to the artifice of representation and reminding the viewer of the impossibility of accurately reconstructing history. $H 3$ offers a new version of Irish republican masculinity, "one that tries to allow for individual psychology as well as communal solidarity, and one that blends the transcendent and the material, the pious and the practical" (138). All three films, Scarlata argues, approach heroic nationalism by presenting death as a means of achieving political gain, although with varying constructions of history and gender in the process. Ultimately Scarlata explores how traditional cinematic representations of militant and aggressive masculinity are necessarily tempered to accommodate the blanket men's use of pain and suffering as a means of resistance, evoking the sentiments of the War of Independence hunger striker Terence MacSwiney: "It is not those who can inflict the most but those who can suffer the most, who will conquer" (29). This framework informs Scarlata's examination of the invisibility and silence of women prisoners within her subsequent analyses of Silent Grace, set in Armagh's women's prisons in 1980, and Anne Devlin, based on the events of the 1803 rebellion from the perspective of Robert Emmet's housekeeper.

Scarlata's consideration of internment extends beyond the policies of the British administration to further explore the Catholic Church's incarceration of women in Magdalene laundries. The correlations between the treatment of male and female prisoners and the female penitents are clear: beatings, stripping, jeering at vulnerable naked bodies, enforced haircuts etc. Examining this process of "internment...behind convent walls" for unmarried mothers, victims of rape and abuse and women considered to be of dubious moral fibre, Scarlata contextualizes the "detention of women without trial for 'crimes' committed against a nationalist ideal of female purity"(203) before exploring its representation in The Magdalene Sisters and Sinners. Here, Catholic Irish nationalism is the colonizing force, vanquishing and occupying the "impure" female body. Both films depict the horrific cruelties inflicted in the institutions and while both protagonists escape the laundries, a sense of entrapment enforced by the patriarchal forces of the Irish nuclear family and the religious control of the Catholic Church persists, leaving the spectator without emotional release. Again, the artifice of cinema is raised by reference to a particular scene in The Magdalene Sisters which depicts abusive priest Fr. Fitzroy filming nuns and penitents in the laundry gardens with his cinecamera. Scarlata asserts that the sequence "discredits a staple of the traditional archive and a weapon in the arsenal of 'reality' - non-fiction footage - by revealing that what passes for the real is only as reliable as the person behind the camera" (2014: 241). Indeed, Sunniva O'Flynn has commented on further complexities connected to this scene: it was informed by the director's research into the clerical collections of the Irish Film Archive. The scene is a loosely re-enacted sequence from the Delaney collection of the grounds and inhabitants of a Magdalene laundry in Dublin in the 1930s. O'Flynn raises questions about the blurring here between fact and fiction (2004: 50) and there is certainly room for ethical debate around Mullan's mining of the archive, which necessarily draws comparisons between the 
original amateur filmmaker and the grotesque voyeur presented in the narrative film.

One of the highlights of the book is the attention it pays to the extraordinary work of Pat Murphy, in its exploration of Maeve and Anne Devlin from the perspectives of both their cinematic achievement and their radical politics. Murphy's aim was to examine women's participation in nationalist history by eschewing romantic notions of female involvement with the "cause" and exploring the less dramatic, sidelined contributions of those who were often frustrated at their marginalization from politics. Murphy does this through avant-garde filmmaking that challenges the spectator in both content and form. Maeve defiantly mobilizes the male gaze in one particular scene with a long take lingering over the main protagonist's naked body as she discusses life in Belfast as a woman with her sister. As Martin McLoone has noted, the camera "lingers so long over the shot that it challenges the (male) audience to question why the scene is constructed in this way. The viewer is then forced to ask questions about how and why the female form is usually displayed in cinema"
(2000: 143). Similarly in Anne Devlin, the protagonist is rarely at the centre of the frame and she critiques her own narrative world and that of the cinematic spectacle, from the sidelines. Devlin's silence in the film (again a six minute long take is used in a scene depicting her interrogation) also operates as an act of defiance against both colonial patriarchy and filmic excess and artifice. As a filmmaker, Murphy has significantly contributed to debates on gender, nationalism, and representation in film more generally and Scarlata's analysis of these two films does much to remind students and scholars of Irish cinema of the importance of Murphy's oeuvre. Indeed, these and the other close textual analyses provided in this study will be useful for teaching purposes and the book will be of interest to students and scholars across the fields of film studies, Irish studies, postcolonialism, gender and history. Both the aesthetics and the structure of Murphy's work critiques simultaneously nationalist history (and its representation) and cinema itself, a feat the author has also achieved in Rethinking Occupied Ireland.

\section{Works Cited}

Blaney, Aileen. 2006. "From Waste to Worth: the Politics of Self-sacrifice in H3". National Cinemas and World Cinema. Eds. Kevin Rockett and John Hill. Dublin: Four Courts Press. 79-92.

McLoone, Martin. 2000. Irish Film: The Emergence of a Contemporary Cinema. London: British Film Institute.

O'Flynn, Sunniva. 2004. "Black and White and Collar Films: Exploring the Irish Film Archive of Clerical Collections". Keeping it Real: Irish Film and Television. Eds. Ruth Barton and Harvey O'Brien. London: Wallflower Press. 39-51.

Prisons Memory Archive. http://prisonsmemoryarchive.com/ [retrieved: 31/12/2015].

Dr Ciara Chambers is a Lecturer in Film Studies in the School of Media, Film \& Journalism at Ulster University. She has published on newsreels and amateur film in various edited collections and journals and is currently writing and associate producing Éire na Nuachtscannán with Mac MacDara Ó Curraidhín (LMDÓC), a BAI funded television series based on her monograph Ireland in the Newsreels (Irish Academic Press, 2012) to be broadcast on TG4 in 2016. 
Making Time in Stanley Kubrick's Barry Lyndon. Art, History, and Empire

Maria Pramaggiore

New York and London: Bloomsbury Academic, 2015

ISBN: 978-1441198075

\section{Reviewer: Elisa Pezzotta}

I consider Stanley Kubrick one of the major auteurs of the twentieth century because whenever I re-watch one of his films, my viewing experience changes. And time is for me one of the more compelling concepts. Although our life is dominated by it, we are unable to grasp it: it is omnipresent, but abstract, it schedules our days, but melds our present with our past and future and, even if we live for a few decades, it discloses to us the idea of eternity. Although the pace of time is measurable and perfect, our experience of it is always different, much like my experience of Kubrick's oeuvre. Thus I welcomed Maria Pramaggiore's book with enthusiasm because it proposes a discussion of how one of the greatest directors 'created' time, sharing his experience of it with us.

Stanley Kubrick's Barry Lyndon (1975) was adapted from William Makepeace Thackeray's novel The Memoirs of Barry Lyndon, Esq., Of the Kingdom of Ireland (1856). The story follows the rise and fall of Redmond Barry (played by Ryan O'Neal in the film) during almost all of his life: from the 1750s, when his father is killed in a duel; through the Seven Years' War (1754-63); to the final scene set in 1789, when the French Revolution began. American audiences failed to relate the Vietnam War, which ended in 1975, the year the film was released, to the Seven Years' War, which is regarded as one of the first world wars because of its imperial ambitions. The protagonist Barry is an Irishman; the Calcutta-born Thackeray was English and married an Irish woman; and Kubrick was an American director living and working in the United Kingdom, who began to shoot his Barry Lyndon on location in Ireland, but had to retreat to the United Kingdom after the IRA's campaign of violence in 1972. These clues let us realize how much history and Irishness, from a national and transnational, colonial and postcolonial point of view, are intertwined in the diegesis of the film and in the extradiegetic context of the history of its making and reception. Kubrick is an auteur and "Thackeray's inquiry into fictional and historical narratives provides Kubrick with a means of addressing the relationships among narrative form, history, and cinematic time, a nexus of interest that recurs throughout the director's films" (2015: 26).

Pramaggiore summarizes her goal when she explains: "I became interested in the way Barry Lyndon produces temporality, and I began to think of the way emotions and critical judgements are intertwined in that process as the creation of aesthetic time" (2015: 9).

Paradoxically, the majority of the criticisms of the film concerned its temporality, although scholars have not previously discussed this controversial feature in depth. Firstly, the film's production period was considered excessive, but the director had to deal with several unforeseen difficulties. Secondly, the film's genre, costume drama, was perceived as obsolete although, during the 1970s, both the American and British film industry released period films. Barry Lyndon's failure was a consequence of its implications of genre, gender, and stardom: it is a costume drama, a literary adaptation, and an epic; it participates in "the feminization of history achieved by the costume romance film" (185); and Ryan O'Neal's star persona was that of a "feminist man" (186). Finally, the film's running time, 184 minutes plus intermission, was

ISSN 1699-311X 
judged exaggerated, despite other films of equally excessive length being released in the 1970s. Robert Altman, Ingmar Bergman, Bernardo Bertolucci, Francis Ford Coppola, Rainer Werner Fassbinder, David Lean, and Stanley Kubrick "have been retroactively designated the progenitors of 'slow cinema"' (2015: 19). Barry Lyndon's slowness is achieved through its ASL of 13 seconds, long takes, centred, static compositions, characters and objects that move slowly, and the circularity of narrative that at the end brings its protagonist back to his Irish, humble origins.

These features are responsible for the charges of boredom made against the film. Pramaggiore cites Heidegger's third form of boredom, profound boredom, because this mood "redirects attention to thought itself and to the passage of time" (2015: 41). Although profound boredom is an incisive concept to explain how spectators are led, through slowness, to reflect upon time, and was used, for example, by John Rhym to comment the last scene of L'eclisse (Michelangelo Antonioni, 1962), it does not clarify why the majority of the viewers are simply bored by the film. Slowness is a vehicle of profound boredom for those viewers who enjoy the slow pace of the film because it urges them to think about time; but the majority of the spectators impatiently wait for the film to end. Why is there this difference among viewing experiences? This question, posed indirectly, is left unanswered.

Both Thackeray and Kubrick were interested in the figure of Napoleon: the writer met the leader twice, wrote several times about him, and set Vanity Fair (1848), which the director considered adapting, during the Napoleonic Wars; and Kubrick did extensive research around shooting a film about the Emperor. Following the chronology of history, the story of Barry Lyndon ends in 1789, the year of the beginning of the French Revolution, when Napoleon rose to prominence, and Barry's braveness foreshadows Napoleon's. Following the chronology of Kubrick's projects, Napoleon precedes Barry Lyndon, and the Emperor's ambition and failure mimic Barry's rise and fall. The fascination with
Napoleon is not the only link between Thackeray and Kubrick: they shared physical and biographical resemblances; they adopted caricature and satire to lay bare the hypocrisy of the military and high society; and they believed that visual imagery can create a tension with narrative elements producing "a temporal delay in the experience of reading or watching. This is the structure that produces the possibility of aesthetic time, of thinking and feeling" (2015: 67). In Kubrick's film the intertitles, the third-person voice-over narrator, the juxtaposition of paintings and characters, and the reverse zoom translate the temporal delay that in Thackeray's faux memoir is achieved through the adoption of a first-person unreliable narrator.

Through the strategy of narratus interruptus, both the writer and the director "foreground the cause-and-effect sequence through which the events are represented, providing a particular experience of narrative while at the same time asking readers and viewers to think about that form of time" (2015: 95). This technique, together with the back and forth, unreliable reading and watching process, challenges the idea that individuals' wills and actions shape history, and that the latter follows a straight, chronological timeline directed towards progress.

Thackeray's novel is an adaptation of his The Luck of Barry Lyndon: A Romance of the Last Century, edited by George Savage Fitz-Boodle, published in instalments in Fraser's Magazine (1844). The temporal delay of the publication of the instalments underscored that of the readers' experience, and is adapted by Kubrick through interruptions, pauses, and the intermission. In the cinematographic medium, slowness expands the experience of the present moment that, thanks to the plot, is haunted both by the past, the killing of Barry's father, and the future, the death of Barry's son. Past, present and future coexist, as in Henri Bergson's duration and Gilles Deleuze's time-image. The film is defined as a palimpsest because, under the layer of present structures, it discloses strata of past designs. Voice-over narration, intertitles, the choice of staging Barry's marriage in Part II, entitled "Containing an Account of the Misfortunes and Disasters 
Which Befell Barry Lyndon", and the several changes of the protagonist's name, disclose that histories and identities are revised over time. “Thackeray and Kubrick's rejection of historical realism is also a realization that history is an aesthetic endeavour" (2015: 109).

The film's narration and its production process undermine the causal logic and the linearity of colonial time, introducing repetitions, circularities, and a return of the repressed. On the one hand, the recurrence of duels, fights, and deaths imbues the narration with cyclical patterns; on the other hand, the IRA's violent actions envelop the film's production with British colonial history, the film's historical background. Moreover, thanks to slowness, the characters' facial and physical expressiveness, musical choices, the mise-en-scène and reverse zoom shots that isolate the protagonist, the director represents Irishness through the ideological frame of a postcolonial or racial melancholia. The latter is related to Irish national identity because "it implies a pathological inability to recover from the losses suffered under centuries of British colonial rule" (2015: 133). Similarly, Barry's colonial Irish body can be described by the figure of the "Anglicized Celt", which "is defined doubly by a thwarted ambition to acquire an unattainable Englishness and a repressed identification with a Gaelic culture that is reviled and revered" (2015: 130). As Kubrick's production remained trapped in the cyclical temporalities of postcolonial conflict, the wan-derer Barry is imprisoned in the repetitions of losses and failures: Barry Lyndon is an Irish odyssey.

Together with melancholia, Kubrick adapts another ideological frame that participates in a colonialist figuring of Ireland, and that regards the relationship between landscape and portrait painting: the eighteenth century debate about the beautiful, the picturesque, and the sublime (2015: 46, 128, 154). Pramaggiore adopts the word sublime to connote Barry's violence (2015: 137, 142), and Irish violence (139), and to contrast it with the picturesque landscape (137, 142), and the rational (184). In Chapter I, as in the
Introduction (10), she claims: "This experience (of aesthetic time), which allows for the synthesis of affect and judgement, should not be confused with the aesthetic of the Romantic sublime" (39); but she uses the expression "sublime linguistic confusion" (77), and a paragraph of Chapter I is entitled "Boredom, or the slow sublime". The relation between boredom and the sublime, and the connection between slow and sublime remain unclear to me; and the title, linking the experience of time and the sublime, seems to contradict the statement cited above.

Whereas the other chapters discuss the "irreversibility of events (the sense of before and after)", and the "repeatability of events", Chapter $\mathrm{V}$ regards the "contemporaneity of the noncontemporaneous (or, the coexistence of multiple time)", that are, according to Reinhart Koselleck, "the three primary modes of temporal experience" within modernity (2015: 45). The latter is present in the film through: anachronism, with the adaptation of the nineteenth century painter Adolph Menzel to shoot candlelight scenes, and the choice of Franz Schubert's Piano Trio in E Flat composed in 1827; and the use of paintings in the mise-en-scène that allow a comparison between the spatio-temporal experiences offered by the cinematographic and the pictorial medium. The spectators' oscillation between these two media highlights both the characters' entrapment in their social milieu and in the aesthetic forms that surround them, and the viewers' reflections about the characters' role in history and fiction. Kubrick adopts eighteenth century paintings because they embody the charm of history, help to create the mise-enscène and, at the same time, suggest that other media have taken the place of painting. Moreover, if these paintings are adapted to recreate the reality of the eighteenth century, they lay bare the relativity of the idea of realism, and reproduce the rhetoric of colonization.

This brief review cannot do justice to Pramaggiore's interesting and compelling work. The book offers considerable information and explanation, much of which was obtained through research carried out at the Stanley Kubrick 
Archive and at the Warner Brothers archive, and

allows for a "synthesis of affect and judgement".

\section{Work Cited}

Rhym, John. 2012. "Towards a Phenomenology of Cinematic Mood: Boredom and the Affect of Time in Antonioni's L'eclisse". New Literary History. Vol. 43. 477-501.

Elisa Pezzotta received her Ph.D. in Film \& Television Studies, Roehampton University, London, and is Cultore della materia of History \& Critique of Cinema at Bergamo University. She has published essays in Wide Screen, Alphaville Journal, Journal of Adaptation in Film \& Performance, Adaptation, and in Ai confini della comprensione (Stefano Ghislotti ed., Bergamo: Lubrina Editore, 2012). She is the author of Stanley Kubrick: Adapting the Sublime (2013), Atlanta: Mississippi University Press. 
Ireland and Cinema: Culture and Contexts

Barry Monahan (ed.)

London: Palgrave Macmillan, 2015.

ISBN 978-1-137-49635-5. Hb 216 pp.

Reviewer: Lance Pettitt

This volume of essays, based on a conference held in University College Cork, makes a strong intervention in the proliferating academic literature on Irish cinema. Its appearance in 2015/16 comes as two key figures in Irish cinema scholarship, Martin McLoone (University of Ulster) and Kevin Rockett (University of Dublin, Trinity College) have taken formal retirement from academic life. And, in a sense, Ireland and Cinema, with its reversed title of the seminal Cinema and Ireland (1987) is an echo-sounding of its concerns - albeit for a new generation, in a transformed environment for cinema and a format of collected essays rather than a co-authored study. The review of the current volume appears in the context of the recognition of Irish achievements in this season's BAFTAs and Academy Awards in the UK and US. The Oscar honours went to Benjamin Cleary's Best Short Film award Stutterer (2015) but other talent that has come to the fore includes: for screen writing (Emma Donoghue's adaptation of Room [2015]), direction (by Lenny Abrahamson, ditto, and John Crowley [Brooklyn 2015]), and Saoirse Ronan's performance in Brooklyn. These are just one kind of context to consider the relationship between Ireland and cinema. This book suggests a healthier, wider frame of reference through its contributors.

The foreword by Martin McLoone is a career coda by a distinguished scholar, inspiring teacher and generous colleague whose own contribution to screen studies in Ireland is woven modestly into the weft of this book and whose influence is evidenced in its index. But careful to strike a critical note in his prefatory reflections, McLoone rightly insists that his motivation is "more pedagogic than self-obsessed, more political than personal [and that] the present has a history, the now has a past" (2015: i, emphasis in original). What follows is a nuanced and insightful essay on the cultural politics of the previous 40 years of activity in Ireland in terms of film production, yes, but just as importantly all the surrounding stuff like festival organisation, promotion, funding schemes and political regimes, archive work, summer schools and university courses and the whole umbrella of international conditions within which small national cinemas have had to operate since the late-1960s to the present. Indeed, drawing on a series of episodes of critical film discussion that has fed into the development of an Irish screen culture in its widest sense, McLoone argues that today "rather than seeing the situation as a national cinema in itself, it is better to see developments in Ireland, north and south, as the successful integration of Ireland into an international screen culture" (2015: xiv) Ireland in this view is not unlike the UK and indeed, other small film production nations in the shadow of the Hollywood behemoth and dwarfed in scale by Bollywood for sheer output. While McLoone writes intimately and supportively about the political aesthetic of films in the Irish new wave period of the 1970s and 80s, he has always been much more open to the possibilities of genre movies and popular forms of TV production than, say Kevin Rockett, who was apt to dismiss much of the indigenous output of film

ISSN 1699-311X 
from the second Film Board period (post-1993) for its apolitical and unadventurous formal blandness. McLoone (2008, 2000) has in previous work been assiduous in locating Irish cinema within a number of international contexts, and he also comments favourably on how Ireland has "emerged as a production site for [...] cutting-edge narrative television [which] is no mean achievement and one that couldn't have been envisaged in the 1980s" (2015: xv). He follows this up with what he sees as the second main shift for screen studies to acknowledge, which is the fact of seeing film not in isolation but as part of a wider field of "image-making" production, activity and circulation that encompasses gaming, animation, digital publishing and so on. Turning to the education context for understanding these new forms, of training for production and the place of theory, McLoone is politically critical of the demise of higher education in Ireland and Britain. He argues for sustaining what he calls a " "critical project" that lies at the heart of all cultural analysis... [that would]...have its own creative dynamic, pushing and suggesting, making connections and offering readings that ultimately adhere to no other agenda than the educational in its broadest sense" (2015: xvii).

Such a "Foreword" concisely frames Monahan's collection which stands as an attempt to address the impulse and need for such a critical creative project. It follows on well from and bears comparison with Werner Huber and Seán Crosson eds. Contemporary Irish Film (2011). Monahan's book provides an introduction that sets out a well-reasoned rationale for his structure and the variety of approaches that are given space in the volume, but I did think that his book's subtitle - "Culture and Contexts" - could have been brought out more explicitly in his introduction. The scope and inclusivity achieved in Ireland and Cinema is admirable and no mean feat: four main parts dealing with "The Politics of Home", "Gender and Stardom", "Northern Ireland" and "Overseas Perspectives". To start with the last, most difficult to 'package' and title, it was in fact one of the most enjoyable, featuring contributions that imagined
Ireland in and from Germany, France, Italy and Brazil. The essays herein include Fergal Lenehan's study of Irish-themed musicals across a period from the 1930s to the 1960s, focusing on the case study of Nur de Wind (Only the Wind, Umgelter 1961); Le Corff's pithy critique of French press coverage of Irish films and the difficulty of empirically analyzing how Irish films circulate in the EU; Borges' analysis of The Field as adaptation of stage-to-screen and an interview-format piece with Susanna Pellis explaining the phenomenon of an Irish film festival in Rome to Ciara Chambers and Barry Monahan.

This brief summary of one part indicates what a reader of this volume can expect in the rest of the contributions. In Part III on "Northern Ireland" there are essays that are comparative in their theoretical position, notably the "Belfast to Bamko" piece by Stephen Baker and Greg McLaughlin looking at anti-capitalist alternative filmmaking practice in conflict and post-conflict societies and Laura Aguiar's study of collaborative filmmaking in "transitional Northern Ireland". The internationalist perspective suggested by McLoone's work and an ongoing interest in filmmaking practice are two threads through the collection as a whole. Brigitte Bastiat's essay on adaptation in the film of Mickybo and Me (Loane 2004) is in the "Northern Ireland" section, but it clearly sits well alongside some essays just mentioned that follow it in Part IV. She looks at the matter of rescripting for international audiences and subtitling. This topic links up well with Nicholas O'Riordan's novel approach to film via his interest in socio-linguistics of accent change set within a critical history of language, misrepresentation and identity debates. This essay by a promising doctoral candidate gelled with others on translation, hybridity and adaptation, but was given a particular linguistic grounding that was refreshing to read. The essays in the book as a whole varied in that some managed well to condense analysis of broader areas or a longer period, whereas others chose to focus in on one film or case study to make their arguments. 
In Part III, Merivirta's essay on the suffering male body in Hunger (McQueen 2008) would have sat equally well in Part II but was no less of an achievement in arguing for an expanded contextualization of the films' analysis of martyr-figures. The film forces us to confront the central role of gendered violence and gendered political oppression which are, in a completely different calibration of genre films, the subject of the four essays in Part II. The 'politics' here are sexual politics and gendered representation in popular screen images of female stardom (Barrett), and the interaction between gender and ethnicity in Barrett's and Dibeltulo's essay on P.S. I Love You (LaGravenese 2007). Perhaps the most trenchantly argued piece in Part II was Patricia Neville's critique of His \& Hers (Wardrop 2008). Bucking the trend of almost universal admiration for Ken Wardrop's film, she concluded that "it does little to interrogate or challenge the conventions of Irish femininity in Irish film and society" (2015: 102).

Perhaps the most deeply theoretically engaged of the essays is Conn Holohan's assured examination of home and space in Irish cinema, coming as it does at the reappearance of the phenomenon of emigration post-2008. He puts the spotlight again on the key concepts "homespace" and "belonging" for a country whose transnational status is deeply imbricated in the cultural memory of Irish people and whose sense of self is based on the default setting of dislocation. In one of the essays that directly addresses class in the book, Jenny Knell's essay examines representations of gangland Dublin in relation to gender and space in a clutch of films from the late-1990s to 2003, in the rising "boom" years of Ireland's economic expansion. Knell's essay focuses on gendered social mobility in relation to space - spatial locations in and around the city; domestic locations and their interior spaces - noting the resilience of entrenched stereotypes of criminalized (working) classes and women within neo-conservative middle-classes (2015: 33).

Overall then, this book exemplifies what Monahan terms the potential value of 'polyvocality and thematic variety' in current criticism about Ireland and cinema. It is an excellent, well-produced and high quality companion to consider the field and what is possible for the creative, educative project envisaged by McLoone. The book's contributors - many of them current doctoral students or early career researchers, globally spread - will perhaps form a third-Irish-wave of critics, commentators and educationalists. We will need them to digest and partake in contemporary debates about the decade that moved from Post-Troubles to the Celtic Tiger to the Crash and on into this officially-declared present moment of cinema and commemoration that sees the premieres of a living history docudrama A Terrible Beauty (Farrell 2016), Kevin McCann's The Rising (2016) and the Notre-Dame led 1916: The Irish Rebellion (Collins/Magan 2016).

\section{Works Cited}

Crosson, Seán and Werner Huber (eds.). 2011. Contemporary Irish Film: New Perspectives on a National Cinema. Vienna: Braumüller.

McLoone, Martin. 2007. "Ireland”.The Cinema of Small Nations. Ed. Mette Hjortand Duncan Petrie. Edinburgh: Edinburgh University Press. 60-75.

McLoone, Martin. 2000. Irish Film. The Emergence of a Contemporary Cinema. London: British Film Institute.

Professor Lance Pettitt is Director of the Centre for Irish Studies at St Mary's University in London, teaching on its MA and PhD programmes, and in 2016, he is concurrently Visiting Professor at the University of Wien, Austria. He is co-series editor (with Beatriz Kopschitz Bastos) of 'Ireland on Film' whose next title is The Road to God Knows Where (2016, Alan Gilsenan) and co-curator of the 'Irish Lives' festival in Brazil (May 2016). His blog is at: www.lancepettitt.com. 
Visions of Ireland Gael Linn's Amharc Éireann film Series, 1956-1964

B. Mairéad Pratschke

Reimaging Ireland Vol. 65, ed. Dr Eamon Maher

Oxford: Peter Lang, 2015

ISBN 9783034318723

\section{Reviewer: Seaghan Mac an tSionnaigh}

The 2015 publication of Visions of Ireland Gael Linn's Amharc Éireann film Series, 19561964 heralds for Mairéad Pratschke the culmination of an admirably substantial research project spanning at least ten years; "A Look at (Irish-Ireland): Gael Linn's Amharc Éireann series, 1956-1964" appeared in the autumn 2005 edition of New Hibernia Review during the "earliest days" of the undertaking (2015: viii). The 'Amharc Éireann' films constituted a series of documentary films on the subject of Irish life, made and first broadcast in well attended Irish movie theatres during the period under discussion. Although few of the literary sources cited in Visions of Ireland are $21^{\text {st }}$ century publications, with only one of them hailing from the five year period preceding the completion of this work, the scope of her reading is no less apparent. The same can be said of the primary research conducted as part of which, for example, she consulted with Colm Ó Laoghaire's (the series producer) daughter (2015: 246) as well as taking the time in so doing to familiarise herself with eight years of "nigh-on unseen" archival footage (in the slightly hyperbolic words of the Irish Film and Television Network; 2010).

The arrangement of her filmography section in the back of the book reflects the overarching two-part distinction between the "Eyes of Ireland" documentary films, to which are devoted the two chapters of Part 1 , and the Gaelic newsreels, which are dealt with over the four chapters of Part 2. The short single-item "Eyes of Ireland" films, or "vest pocket documentaries" as Ó Laoghaire called them (Ó Laoghaire 1957), are all titled bilingually, whereas the "Gaelic News" films of the second series rather ironically sport monolingual English titles. Pratschke deals with twenty-six of the thirty-six films in the initial "Eyes of Ireland" series. The "Gaelic News", after the inaugural trial issue, ran through a further 269 editions, or éagrán [sic] as in an endearing imitation of contemporary usage she occasionally terms them. Each of the 270 'eagrán' was further divided into two, three, or four segments. Although Pratschke could not possibly have dealt in any detail with each and every one, she manages to comment informatively on almost two hundred segments in total, with consistent detailed reference to their historical context.

The cover image Pratschke has selected depicts an elderly gentlemen clad in suit as he explores authoritatively a recent feat of aeronautical engineering in the youthful company of some of the very first Irish 'air hostesses'. One eyes with suspicion the workings of Ó Laoghaire's camera crew filming the entire group gathered beside one of the earliest Aer Lingus aircrafts. The scene alludes to Irish womanhood's sudden accession to a modern workforce in an increasingly international free market society, relentless in its march towards dependence on new technology, of which both the jet and the camera documenting it are very immediate examples. The very presence of the tradename Aer Lingus, as a willing deformation of the word "aerloingeas" from which it derives, bears witness to the rather skewed popular perception of the Irish language.

The overall cover design leaves a bit to be desired, but suffice to say that Pratschke's choice of cover image tidily reconciles the social, economic, aesthetic, and ideological criteria by which 
she makes her assessment of Gael Linn's foray into film-making. Other such images as are reproduced nicely complement Pratschke's work, and are an incitement to visit irishphotoarchive.ie, to whom we may be grateful for these precious impressions of Ireland in this period. One might have welcomed the interspersion throughout the text of some screen captures from the films themselves, courtesy of the ever helpful Sunniva O'Flynn, who is thanked twice in the book (2015: 1).

An introduction outlines the novelty of the Amharc Éireann (or 'Views of Ireland') series as a brave undertaking which finally put the Irish language on screen (2015: 1). By way of both comparison and association, Pratschke reminds us that before Gael Linn's venture, the residual Irish language culture had been conserved by means of the Mobile Recording Unit operated by folklorists such as Pronsias Ó Conluain and Séamus Ennis, whose research involved six years travelling the west on a bicycle 2015: 208). The newfangled newsreels were originally heard as Gaeilge without English subtitles, and, just as later TG4, RTÉ, and BBC reappropriations of original Gael Linn footage would impose subtitles, Pratschke ably interprets the commentary by means of her own translations.

Pratschke goes on to draw attention to the historiographical significance of her pertinent response to Harvey O'Brien's call to engage critically with the Amharc Éireann films (2015: 2) in light of Louis Marcus' The Years of Change (1996), which O'Brien accused of robbing the series of "its specificity by historical distance" (O'Brien 2000: 345). Pratschke proceeds to outline the events leading up to the commissioning of Colm Ó Laoghaire's project in 1956 (23), through to its discontinuation which is attributed rather matter of factly to the failure of Gael Linn's bid to become the national broadcaster (233). Chapter two deals with industry, attempting to resolve a tension, perceived to be inherent in the films, between the abstract importance of native industry for Irish identity and the more immediate necessity for foreign involvement. Chapter three focuses on their presentation of the increasingly active tourism industry in Ireland, closing with an account of the kinds of insights into Irish society to be gained from a consideration of the films' treatment of gender issues in the Irish workforce. In obvious anticipation of the series of 1916 commemorations scheduled for 2016, Pratschke devotes chapter four (derived from a previously published article available online) to a discussion of the films dealing with various state historical commemorations and heritage tourism, along with the symbolism that these involved. Chapter five deals with the Republic's relation with its diaspora as well as its approach to foreign affairs, accounting for the country's progression from emboldened role model for fellow decolonising nations to world weary member of an international community increasingly burdened with the complexities of peacekeeping on a postcolonial planet. Chapters six and seven identify the ramifications of the very sudden changes described in the preceding chapters, as well as those of urbanisation, for both the social and physical landscape of Ireland, and chapter eight considers how the same factors informed popular perceptions of the Irish language, its decline in later years, and the relevance of Gael Linn amidst such developments.

The overall critical engagement yields the conclusion that the films' commentary betrays an anti-modern tension between past and present, a conclusion at odds with the progressive outlook identified by other critics. In one film, for example, a racially integrated Dublin student demonstration is depicted during their march in solidarity with black South Africans. This is, according to an anecdote recounted by Sarah Pierce, who values the Amharc Éireann series for the challenges it mounts to traditional accounts of the past, in contradiction of dinner table claims thirty years later that only for the previous five or so years were "black people" to be seen in Ireland (Pierce 2009). Of a similar opinion is Joe Marcus (son of Gael Linn documentarist, Louis Marcus), director and producer of Amharc Aneas (2010), a four-part documentary series compiled from the Amharc Éireann footage, and subsequently broadcast on BBC and TG4, yet curiously ignored by Pratschke. Marcus Junior speaks of the admirable disregard for the sectarianism of the era, evident in a report on the 
$12^{\text {th }}$ of July parades in Belfast featuring the comment "this is the only black Orangeman we found" (IFTN 2010). However, if such throwaway lines can be said to favour competing narratives of the past, other lines serve to confirm prejudices traditionally ascribed to the period. Pratschke takes particular issue with a comment made in "Mná Spéire (Air Hostess Training)", as the camera pans across prospective Aer Lingus flight attendants undertaking exams, that "there is no question on how to pick up a rich passenger" (2015: 76).

However, her objection to the articulation of the history of Waterford Glass in "Gloine Phortlairge", on the grounds that Ó Laoghaire seems to avoid mention of the fact that the thriving initiative was founded by Anglo-Irish stock 2015: 42), seems about as relevant as if the film-maker had been criticised for having neglected to recall that glass was invented in Mesapotamia in 3500BC. One wonders whether an unironic anachronistic reference to O'Connell Street as "Sackville Street" (2015: 4) is intended as an ever so slightly retaliatory gesture towards proponents of the republican narrative, of whom Pratschke is too often too dismissive.

Thus, the possibly legitimate concerns of cultural nationalist politicians who bemoaned the prevalence of British and American productions due to their affording an unfair advantage to the English language are, for example, said to be less "cerebral" than those of Seán McEntee who is lauded for his campaign to introduce Russian cinema to Irish theatres (2015: 6). On the other hand, Pratschke disputes the cultural sophistication of politicians whose reluctance to invest in Georgian Dublin was based on a stance of postcolonialism and argues that this contributed to a degenerating housing situation in which those Dubliners lucky enough to have escaped collapsing tenements were ignobly located to tiny temporary dwellings (2015: 42). That the gravity of the situation was overlooked during the period is fairly demonstrated by Pratschke who objects to an Amharc Éireann commentator's remark that the minute caravans, presented rather deceptively as a "modern cottages", had "every comfort in them - water, cooking, facilities - and [were] decorated very nicely". "Another benefit", he continued, was "the space", and Pratschke rightfully upbraids him for this "joke made in very poor taste" (2015: 172). Writing in 2015, Pratschke does well to highlight this aspect of the human cost associated with a period of rapid social and economic transformation, in which rural Ireland, the travelling community, as well as the urban working class, were being left behind, issues that are part of a trend which continues to the present day.

Pratschke quite rightly finds issue with the series' willingness to uphold state ideology, and in so doing makes explicit many of the rather implicit expressions of support in the series for the Fianna Fáil government of the period during which it was made. Pratschke notes the glaring absence of pro-treaty figures such as Michael Collins and Arthur Griffith, and of left-leaning Jim Larkin and James Connolly (2015: 104, 168). Similarly, however, Pratschke herself omits to name the "leading Gaelic League members", such as Páraic Ó Máille, Fionán Lynch, and of course, Éamonn de Valera, who went on to become key figures in Free State political life. Seemingly indifferent to accepted modern language planning practices, Pratschke saddles the governmental successor of the Gaelic League with the blame for having institutionalised the language, a phenomena to which she in turn attributes the later disappearance of the Irish language (2015: 21), without offering as much as a mitigating reference to the tremendous work done by that cultural organisation up until its having been declared illegal in 1919 by the British State. Indeed, she makes clear her admiration for Gael Linn's ability to operate almost independently of state funding later on (2015: 226). In another context, however, with broadcaster RTÉ's foundation independent of the civil service, it is precisely the de-institutionalisation of the Irish language which is identified as contributing to the reduction of its stature in Ireland (2015: 237).

Mairéad B. Pratschke, in coming to these conclusions, shrewdly discerns the subtle expression of a particularly "Irish-Ireland" ideology in the Amharc Éireann films. Of course, it should come as no shock that an Irish series 
which Pratschke herself categorises as a "cultural nationalist project" (2015: 2) might appeal to "Irish-Ireland" sensibilities. It is, however, not the business of Visions of Ireland with its express aim of restoring an awareness of "historical specificity" to discussions of the series, to compensate for any breaches of subjectivity on the part of Colm Ó Laoghaire and his crew. Outright historical objectivity, then, is not one of the many merits that may be ascribed to Pratschke's compelling text. Although at times appearing too eager to criticise perceived proponents of nationalist and republican agendas, Pratschke rightly flags the presence of state propaganda in what was supposed to be the product of independent cultural activity commissioned by Gael Linn.

\section{Works Cited}

IFTN (The Irish Film and Television Network). 2010. "The BBC looks north with Amharc Aneas", 8 March. http://www.iftn.ie/news/?act 1=record\&aid=73\&rid=4282917\&tpl=archnews\&only=1 [retrieved 14/1/2016]

Marcus, Joe. 2010. Cited in "The BBC looks north with Amharc Aneas”, The Irish Film and Television Network. 8 March. http://www.iftn.ie/news/?act1=record\&aid=73\&rid=4282917\&tpl=archnews\&only=1 [retrieved $14 / 1 / 2016]$

O’Brien, Harvey. 2000. "Projecting the Past: historical documentary in Ireland”, Historical Journal of Film, Radio and Television 20.3: 335-50.

Ó Laoghaire, Colm. 1957. "Gael-Linn 'Vest Pocket' Documentaries”, Irish Film Quarterly 1.1 (March). 9 - 11.

Pierce, Sarah. 2009. "The Archival Fourth Dimension”, Afterall. 23 November. http://www.afterall.org/online/the.archival.fourth.dimension\#.VqjcLIIgvIU [retrieved 5/01/2016]

Pratschke, B. Mairéad. 2005. “A Look at (Irish) Ireland: Gael Linn's Amharc Éireann series, 1956-64,” New Hibernia Review 9.3: 17-38.

. 2007. "Resurrecting the Past: Republican Memory in the Amharc Éireann News Film Series, 1959-1964", National Identities 9.4: 369-94.

Seaghan Mac an tSionnaigh is completing his PhD at Mary Immaculate College, Limerick, Ireland. He is the author of The West Limerick Man Who Wrote a Dictionary (LuLu 2015). 